\title{
The Relationship Between Overallotment Options, Underwriting Fees and Price Stabilization For Canadian IPOs*
}

\author{
Richard Chung \\ Concordia University, Canada \\ Lawrence Kryzanowski \\ Concordia University, Canada \\ Ian Rakita \\ Concordia University, Canada
}

The overallotment option (OAO) gives underwriters the right to acquire additional shares from the issuing firm at the offer price (less underwriting fees) in order to meet any excess demand for an issue. Thus, underwriters can use overallotment options to stabilize market prices post-issue by increasing the supply of shares for oversold issues. Unlike IPOs in the U.S., the Canadian evidence finds that OAOs are included less frequently, that underwriting fees are positively associated with $\mathrm{OAO}$ inclusion, and that the $\mathrm{OAO}$ appears to play a minor role in market price stabilization, which is itself less detectable and appears to be limited to the very early stages of secondary market trading. These results suggest that the role of the OAO differs markedly for IPOs in Canadian versus U.S. markets (JEL G10, G15).

Keywords: initial public offerings, overallotment options, price stabilization, underwriting fees.

*We thank P. S. Chen for technical assistance. Financial support from Ned Goodman Chair in Investment Finance, FCAR (Fonds pour la formation de chercheurs et l'Aide à la Recherche), and SSHRC (Social Sciences and Humanities Research Council of Canada) are gratefully acknowledged. We appreciate comments and suggestions from Charles Mossman and participants at presentations at the Northern Finance Association (Winnipeg 1997), and the University of Manitoba and Wilfrid Laurier University.

(Multinational Finance Journal, 2000, vol. 4, no. 1\&2, pp. 5-34)

(C) Multinational Finance Society, a nonprofit corporation. All rights reserved.

DOI: $10.17578 / 4-1 / 2-2$ 


\section{Introduction}

A standard clause that appears in the prospectus of many new equity offerings in Canada reads:

"In connection with this offering, the Underwriters may over-allot or effect transactions which stabilize or maintain the market price of the Common Shares at levels above those which might otherwise prevail in the open market. Such transactions, if commenced, may be discontinued at any time."

The overallotment option (OAO) gives the underwriting syndicate the right to purchase an additional predetermined percentage $(\leq 15 \%)$ of the shares initially offered over a specific secondary market trading period that ranges from a few days up to sixty days. The exercise price for these additional shares is the offer price less the underwriting discount (spread).

OAOs also can be used as an underwriting-fee substitute in the compensation package for underwriters. Carter and Dark (1990) note two potential non-price stabilization benefits of OAOs that may result in underwriting fees being negatively related with the existence of an OAO in an IPO offering. The first benefit is from better underwriting risk management. New IPO issues are typically oversold in expectation of some degree of reneging by investors who initially expressed interest. If reneging is below expectations, underwriters must cover any short positions through secondary market purchases. This is expensive if the issue was significantly underpriced. Thus, the OAO allows the underwriters to oversell and to cover a short position of a known percentage of the initial issue by exercising the OAO.

A second non-price stabilization benefit for underwriters is from better client relations. The underwriter is only able to deliver a fraction of the shares desired by some clients for particularly attractive and overscribed issues. The OAO can enhance the underwriter's reputation by easing this shortfall, and, thus, satisfying more client indications of interest.

As is the case with ordinary options, the lower limit on the value of the $\mathrm{OAO}$ is zero. Thus, everything else held equal, the underwriting fee charged to the issuing firm should be lower as the value of the OAO increases. For initial public offerings (IPOs) and for secondary offerings in the U.S., Carter and Dark (1990) and Hansen, Fuller and Janjigian 
(1987), respectively, find that underwriter spreads are not significantly related to OAOs.

Canadian issuing firms agree less often to OAO inclusion compared to their U.S. counterparts. ${ }^{1}$ A potential reason for the lower frequency of OAO inclusions in Canadian issues may be due to the much lower average level of underpricing of Canadian versus U.S. issues. ${ }^{2}$ While the traditional assumption is that prices evolve according to the unobstructed forces of supply and demand, underwriters with reputation capital at stake cannot be expected to remain idle when a new issue is performing poorly at the start of secondary market trading. If stabilization of market prices occurs for what would otherwise be poorly performing IPOs, the distribution of cross-sectional returns will be left censored, and the mean of this censored distribution may be positive and significant, and will increase with greater stabilization. ${ }^{3}$

Specifically, Ruud (1993) suggests that the distribution of initial returns should be positively skewed and excessively peaked around zero if underwriters stand ready to buy back shares of non-underpriced issues at the offer price. Schultz and Zaman (1994) find evidence that underwriter price support may be achieved by managing the supply of

1. For example, the Carter and Dark (1990) sample contains 439 issues of which 403 (92\%) contain OAOs. This is in sharp contrast to the sample in this study that examines 180 issues of which only $56(31 \%)$ contain OAOs.

2. In the literature, underpricing is computed either as the cross-sectional mean return from the offer price to the closing price on the first day of secondary market trading or from the offer price to the price of the first secondary market trade. A comparison of the literature highlights that U.S. underpricing far exceeds that in Canada. For example, the values listed on J. Ritter's website at ritter@dale.cba.ufl.edu give values of 17.4\% and 6.3\% for U.S. and Canadian IPOs, respectively. An incomplete list of U.S. studies includes Ibbotson (1975), Miller and Reilly (1987), Ibbotson, Sindelar and Ritter (1988) and Barry and Jennings (1993), and of Canadian studies includes Jog and Riding (1987), Cheung and Krinsky (1994), Jog and Srivastava (1996) and Kryzanowski and Rakita (1996).

3. Alternative explanations exist for IPO underpricing. Baron (1982) hypothesizes that underpricing results from asymmetric information between issuing firms and underwriters. Beatty and Ritter (1986) suggest that underpricing is caused by ex ante uncertainty about true IPO value. Rock (1986) attributes underpricing to the winner's curse, which results from the existence of informed and uninformed investors in the new issue market. Tinic (1988) maintains that underpricing is a result of underwriters striving to avoid legal liability. Finally, Welch (1989) contends that underpricing is due to the actions of high quality firms (mimicked by low quality firms) who expect to recapture losses with subsequent seasoned offerings. 
shares. For an oversold offering, a rational underwriter will (not) exercise the OAO to cover the short position if the issue is trading at a price in the aftermarket that is above (below) its issue price net of the underwriting spread. ${ }^{4}$ Chowdhry and Nanda (1996) develop a model where underpricing is generated by both the deliberate relative reduction of the offer price and by stabilization through aftermarket purchases by underwriters at the offer price. Benveniste, Busaba and Wilhelm (1996) argue that primary market efficiency is promoted via the complementary activities of price stabilization and the use of penalty bid provisions to discourage the flipping of poorly received issues. Aggarwal (2000) provides evidence that underwriters primarily provide price support in the aftermarket by covering syndicate short positions and by restricting supply by penalizing "flippers." Ellis, Michaely and O'Hara (2000) uncover evidence that the lead underwriter engages in stabilization activity for poorly performing IPOs and uses the OAO to reduce inventory risk.

Thus, the primary objective of this study is to determine the relationship between OAOs and underwriting fees, and between OAOs and price stabilization for a sample of Canadian IPOs that listed on the Toronto Stock Exchange (TSE) over the period 1984-1993. To this end, whether or not underwriting spreads are negatively and significantly related to the inclusion of an OAO for Canadian IPOs is first examined. The market impact of price support by underwriters near the start of secondary market trading is then measured in order to determine if price stabilization appears to be a primary motive for the inclusion of an OAO for a Canadian IPO. Canadian results are benchmarked against those for the U.S. that have already been reported in the literature.

This research is of particular interest to institutional and private investors who are important participants in the market for new issues, market regulators who are charged with the responsibility of supervising the new issue process, underwriters who must ultimately be held accountable by the issuing firm for the success or failure of an IPO, and to firms in deciding on whether or not to include an OAO in their IPO. The differences between Canadian and U.S. practices should be of interest to the growing number of Canadian firms that are making a

4. Secondary market purchases are used to cover the short position in oversold issues whose aftermarket price is below its offer price net of the underwriting spread. 
choice of whether or not they should go public in Canada, in the U.S. or in both markets simultaneously.

The remainder of this paper is organized as follows. In the next section the data set is described. In section 3 some descriptive statistics on the frequency of overallotment option use and the characteristics of IPOs with overallotment options are provided. In section 4 , the relationship between underwriter fees and the inclusion of an OAO in an IPO is considered. In section 5, evidence of price support (stabilization) as reflected in the distribution of initial IPO returns, in the mean initial IPO return, and in the bid-ask spreads of IPOs in the aftermarket are reported. After finding evidence of market stabilization, whether this market effect depends upon the inclusion of an OAO in an IPO is tested. Concluding remarks are offered in section 6.

\section{Data Description}

Between 1984-93, 463 IPOs are identified using the TSE Annual New Listings Report. In order to maintain sample homogeneity, unit offerings, warrants, preferreds and other hybrids are filtered out so that 262 pure common share issues remain. In order to minimize classification problems, 22 issues with offer prices below $\$ 2$ are deleted. In order to minimize thin trading problems, 7 issues that did not trade at least once per day on average over the first twenty days of trading are excluded. In addition, 12 issues by mining or oil and gas companies and 5 issues with missing information are dropped from the sample. Table 1 gives a year-by-year account of the number of IPOs included in the final sample of 216 issues by industrial companies.

The required data is obtained from the Equity History database compiled by the TSE. This database contains the time stamp, bid, ask and transaction prices, broker clearing numbers, and share trading volumes for every trade and quote on the TSE.

Initially, for each issue, returns are calculated from the offer price to the opening price. This return measure is then used to classify issues in the sample as underpriced or non-underpriced (i.e., correctly priced and overpriced) issues. The full sample of 216 IPOs consists of 106 underpriced issues (49.1\% of the sample), and 110 non-underpriced issues (50.9\% of the sample). 
TABLE 1. IPOs By Year

\begin{tabular}{lcccc}
\hline Year & $\begin{array}{c}\text { IPOs listed } \\
\text { on TSE }\end{array}$ & $\begin{array}{c}\text { IPOs in } \\
\text { Final Sample }\end{array}$ & $\begin{array}{c}\text { IPOs with } \\
\text { No-OAO }^{\mathrm{a}}\end{array}$ & $\begin{array}{c}\text { IPOs with } \\
\text { OAO }\end{array}$ \\
\hline 1984 & 43 & 12 & 7 & 2 \\
1985 & 33 & 8 & 6 & 1 \\
1986 & 113 & 66 & 50 & 5 \\
1987 & 81 & 29 & 18 & 6 \\
1988 & 19 & 2 & 1 & - \\
1989 & 27 & 7 & 4 & 2 \\
1990 & 14 & 4 & 1 & 2 \\
1991 & 17 & 5 & 3 & 4 \\
1992 & 27 & 15 & 7 & 31 \\
1993 & 89 & 68 & 27 & 56 \\
Total & 463 & 216 & 124 & 24 \\
\hline
\end{tabular}

Note: ${ }^{\mathrm{a}} \mathrm{OAO}$ refers to overallotment option.

\section{The Frequency of Overallotment Option Use and the Characteristics of IPOs with Overallotment Options}

The majority of the 180 issues for which a final prospectus was available do not contain an OAO (124 without versus 56 with OAOs). When an $\mathrm{OAO}$ is present, the mean (median) ratio of overallotment shares as a percentage of the number of shares issued is $10.5 \%$ (10.0\%). Based on the frequency distribution of OAO percentage intervals reported in table 2 , the distribution of OAO percentages is bimodal with the two most frequently occurring values being $10 \%$ (20 instances or $36 \%$ of OAO issues) and $15 \%$ (14 instances or $25 \%$ of OAO issues).

The samples of issues with and without OAOs are quite similar. Based on one-sided $t$-tests reported in table 3 , no significant difference exists between the mean offer price, opening price, shares issued, offer size, underpricing at the open, and the day one share volume. However, the mean underwriter spread for the OAO sample is significantly larger than that for the no-OAO sample. While issues with OAOs are expected to have lower fees, everything else held equal, the differences in these means are expected to be explained by other determinants of underwriting fees such as issue size, underwriter reputation and issue riskiness. 
TABLE 2. Distribution of Overallotment Option Frequencies for Various Overallotment Option Percentages of Initial Share Offerings

\begin{tabular}{lrcc}
\hline OAO Range & Frequency & Percent & Cumulative \% \\
\hline 0 & 124 & 68.9 & 68.9 \\
$.001<.025$ & 0 & 0 & 68.9 \\
$.025<.050$ & 3 & 1.7 & 70.6 \\
$.050<.075$ & 5 & 2.8 & 73.3 \\
$.075<.100$ & 10 & 5.6 & 78.9 \\
$.100<.125$ & 21 & 11.7 & 90.6 \\
$.125<.150$ & 3 & 1.7 & 92.2 \\
.150 & 14 & 7.8 & 100 \\
Total & 180 & 100 & \\
\hline
\end{tabular}

TABLE 3. Characteristics of IPOs With/without an Overallotment Option

\begin{tabular}{|c|c|c|c|}
\hline Issue Characteristic & $\begin{array}{c}\text { Mean for } \\
\text { IPOs with OAO }\end{array}$ & $\begin{array}{c}\text { Mean for } \\
\text { IPOs with no-OAO }\end{array}$ & $p$-value \\
\hline Offer Price $(\$)$ & 9.187 & 9.608 & .280 \\
\hline Opening Price (\$) & 9.475 & 9.974 & .244 \\
\hline Shares Issued & $4,909,380$ & $4,470,961$ & .384 \\
\hline Offer Size (\$) & $55,036,638$ & $48,087,932$ & .345 \\
\hline Under Open (\%) & 3.497 & 5.018 & .209 \\
\hline Volume Day1 & 283,788 & 203,603 & .216 \\
\hline Fee $(\%)$ & 6.261 & 5.972 & .050 \\
\hline
\end{tabular}

Note: This table examines a sample of 180 initial public offerings on the Toronto Stock Exchange for the period 1984-1993 for which a final prospectus was available. The sample consists of 56 issues containing an overallotment option and 124 not containing an overallotment option. Underpricing is calculated from the offer price to the opening price on the first day of secondary market trading. Volume Day1 is the number of shares traded on the first day. The fee is the underwriter's spread expressed as a percentage of the offer price. The $p$-values are reported for one-sided $t$-tests for the difference between means. With the exception of the $t$-tests for the differences between means for the percentage of underpricing and for volume, $F$-tests could not reject the hypothesis of equal variances between the two samples for each of the other variables considered in this table. 


\section{Evidence on the Relationship Between Underwriting Fees and the OAO}

The relationship between underwriting fees and the OAO after controlling for these other variables is now examined. Hansen, Fuller and Janjigian (1987) estimate that the OAO is worth about one percent of the gross proceeds of the full issue. Hansen (1986) suggests that the value of the OAO may represent in excess of $9 \%$ of the proceeds collected when the option is exercised. ${ }^{5}$ Since the expected value of the $\mathrm{OAO}$ is certainly non-negative, the inclusion of an OAO in an IPO should logically reduce underwriter fees.

To formally test the hypothesis that underwriting fees and the OAO are negatively related, several explanatory variables are used to control for effects not directly related to the presence of the OAO. The full model can be written as:

$$
\begin{gathered}
\text { Underwriter Fee }(\text { Spread })=\beta_{0}+\beta_{1} \text { Inoffer }+\beta_{2} \text { demand } \\
\quad+\beta_{3} \text { oaoprcnt }+\beta_{4} \text { rank }+\beta_{5} \text { synd }+\beta_{6} \text { retstdev }+\varepsilon
\end{gathered}
$$

The first control variable is lnoffer, which is measured by the natural log of the gross issue value. The larger the issue size the smaller the fee.

5. Several erroneous assumptions lead to a questioning of the reliability of the estimates, which are obtained using the Black-Scholes option pricing model in these studies. First, the strike price of the OAO is assumed to be the offer price, although the underwriter actually pays the offer price less the underwriting fee discount. Second, the OAO is likened to an American call option. It is well known [Merton (1973)] that American calls on assets with no intermediate payouts are equivalent in value to European calls. This suggests that OAOs should never be rationally exercised before maturity. (In fairness, Merton's argument is predicated on there being a market in which options could be traded, which is not the case for OAOs). Third, the most important implicit assumption is that issues are undersold prior to the start of secondary market trading. The majority of new issues are in fact oversold. One syndicate manager estimates the probability of being oversold is $80 \%$. The same syndicate manager estimates that conditional on a new issue being oversold, the range of overselling is $10-400 \%$ ! If an issue is oversold by at least the size of the OAO, the value of an OAO at the start of secondary market trading is certain since the additional shares are sold at the offer price. The underwriter can exercise the option, cover his short position, and effectively earns his spread on the OAO shares. Therefore, the Black-Scholes option pricing model probably is an inappropriate model for estimating $\mathrm{OAO}$ value in the majority of cases. 
Therefore, the sign of $\beta_{1}$ should be negative. The second control variable, demand, measures the number of new issues in a given month. ${ }^{6}$ Carter and Dark (1990) posit that the estimated coefficient of this variable should be negative if underwriters reduce their spread in an effort to induce firms to issue during a window of opportunity. On the other hand, the expectation in this study is that hot issue markets influence a firm's decision to go public because management is willing to pay a premium underwriting fee in order to issue shares when they have a greater probability of being overvalued. Therefore, we posit that the coefficient $\beta_{2}$ should be positive.

The variable, oaoprcnt, is the percentage of OAO shares relative to the number of shares in the issue. ${ }^{7}$ Since the OAO has a non-negative value, it should have a negative or no effect on fees. Therefore, the coefficient $\beta_{3}$ is expected to be negative.

The certification role of the underwriter in IPO issuance has been documented in a number of studies. Beatty and Ritter (1986) find that fairly priced issues are associated with increased underwriter reputation. Carter and Manaster (1990) conclude that prestigious underwriters prefer to be involved in lower risk offerings. Wolfe, Cooperman and Ferris (1994) find that prominent underwriters avoid smaller, riskier issues. The variable, rank, is included to reflect underwriter reputation. Starting in 1984 and using a method similar to Megginson and Weiss (1991), underwriters are ranked in decreasing order according to their total involvement in IPO financing dollars as lead or co-lead underwriters over a five year period. We then roll forward one year, rerank and continue ranking until 1993. Underwriters who are either the lead or co-lead for an issue in 1984 are then assigned a ranking based on the 1984-1988 list of ranks. Lead or co-lead underwriters for issues in 1985 and 1986 are ranked according to the 1985-1989 list of ranks. In turn, underwriters for 1987 and 1988 issues are assigned ranks from the 1986-1990 list, for 1989 and 1990 issues are assigned ranks from the 1987-1991 list, for 1991 and 1992 issues are assigned ranks from the

6. Using the dollar value of the issues in a given month makes no qualitative difference.

7. Two other variations for this regressor are considered herein. The first is a binary variable which takes the value of one if an OAO is granted, and takes on a value of zero otherwise. The second assigns ordinal values to different OAO levels as in table 5. Neither alternative has any material effect on the results subsequently reported. 
TABLE 4. Correlations Between Underwriter Rankings Over Different Periods

\begin{tabular}{lcccccc}
\hline Year & $1984-93$ & $1984-88$ & $1985-89$ & $1986-90$ & $1987-91$ & $1988-92$ \\
\hline $1984-88$ & .85 & & & & & \\
$1985-89$ & .83 & .95 & & & & \\
$1986-90$ & .83 & .93 & .98 & & & \\
$1987-91$ & .79 & .82 & .87 & .91 & & \\
$1988-92$ & .75 & .64 & .69 & .74 & .85 & \\
$1989-93$ & .85 & .57 & .63 & .66 & .71 & .78 \\
\hline
\end{tabular}

1988-1992 list and finally, for 1993 issues are assigned ranks from the 1989-1993 list. To some extent, this procedure accounts for the timevarying nature of underwriter reputation. ${ }^{8}$ The assignment of ranks according to particular five-year windows is somewhat arbitrary. However, based on table 4, the ranks for adjacent five-year periods have high rank correlations, which tend to mitigate any inherent assignment bias. Due to the value of certification and the fact that underwriter reputation is negatively associated with issue risk, the expectation is that the coefficient $\beta_{4}$ will be positive. ${ }^{9}$

The fifth control variable, synd, measures the size of the underwriting syndicate. One important function performed by members of the underwriting syndicate is share distribution. If distribution efforts are facilitated through larger syndicates, higher fees may be justified. Therefore, the sign of the coefficient $\beta_{5}$ is expected to be positive.

The sixth control variable, retstdev, proxies for one type of issue risk. This variable is measured as the standard deviation of daily returns over the first sixty days of trading. Since underwriters need to be compensated for bearing the risk associated with issue success, $\beta_{6}$ is expected to carry a positive sign.

Two interaction variables are included to capture the interaction between the overallotment option percentage and the standard deviation of returns, $o a o \times s t d$, and the interaction between underwriter reputation and the standard deviation of returns, rank $\times s t d$.

8. It is not possible to rank using annual activity due to the small number of issues for several of the years.

9. A rank of one corresponds to the highest reputation level. 
TABLE 5. Ordinary Least Squares Regression Results for the Sample of 180 IPOs over the Period from 1984-93

\begin{tabular}{lcccccc}
\hline Regression & 1 & 2 & 3 & 4 & 5 & 6 \\
\hline Intercept & 15.188 & 14.938 & 16.392 & 15.383 & 14.433 & 16.257 \\
& $(.0001)$ & $(.0001)$ & $(.0001)$ & $(.0001)$ & $(.0001)$ & $(.0001)$ \\
lnoffer & -.590 & -.542 & -.629 & -.603 & -.531 & -0.628 \\
& $(.0001)$ & $(.0001)$ & $(.0001)$ & $(.0001)$ & $(.0001)$ & $(.0001)$ \\
demand & .016 & & & .016 & & .017 \\
& $(.3524)$ & & & $(.3783)$ & & $(.3392)$ \\
oaoprcnt & .027 & .032 & .030 & .057 & .064 & .054 \\
& $(.0149)$ & $(.0032)$ & $(.0073)$ & $(.0316)$ & $(.0154)$ & $(.0412)$ \\
rank & .036 & & -.010 & .034 & .035 & -.010 \\
& $(.0143)$ & & $(.6819)$ & $(.0216)$ & $(.0165)$ & $(.6699)$ \\
synd & .067 & & .053 & .063 & & .049 \\
& $(.1056)$ & & $(.1982)$ & $(.1301)$ & & $(.2387)$ \\
retstdev & .096 & & -.035 & .112 & .106 & -.015 \\
& $(.0125)$ & & $(.5942)$ & $(.0057)$ & $(.0092)$ & $(.8307)$ \\
oaoxstd & & & & -.009 & -.011 & -.007 \\
& & & & $(.2097)$ & $(.1560)$ & $(.3163)$ \\
rank $\times$ std & & .009 & .012 & & & .011 \\
& & $(.0001)$ & $(.0186)$ & & & $(.0246)$ \\
Adj. $R^{2}$ & .527 & .543 & .539 & .528 & .525 & .539 \\
\hline
\end{tabular}

Note: The slope coefficient estimates ( $p$-values) are reported in this table. The dependent variable is the underwriter fee (percentage). Lnoffer is the log of the offer price. Demand measures the number of issues that are offered in the same month. Oaoprent is the overallotment option expressed as a percentage of the number of shares offered and ranges from 0 to 15. Rank is a measure of underwriter reputation where a higher rank indicates a lower reputation. Synd is the number of members in the underwriting syndicate. Retstdev is the standard deviation of daily returns over the first sixty days of secondary market trading. Oaoxstd captures the interaction between the overallotment option percentage and the standard deviation of returns. Rank $\times$ std captures the interaction between underwriter reputation and the standard deviation of returns.

The results for a series of regressions are summarized and reported in table 5. The estimated coefficients for issue size, underwriter reputation and standard deviation of returns in regression one (i.e., equation 1) have the predicted sign, and are all significant at a $p<.05$. While the coefficients for new issue activity and syndicate size are of the predicted sign, they are not statistically different from zero at 
conventional levels. Unlike Carter and Dark (1990) and Hansen, Fuller and Janjigian (1987), the finding here is that the coefficient for the overallotment option percentage is significant (and positive) at $p<0.05$. This suggests that the cost of the OAO is reflected in higher and not lower fees. Due to the reduced incidence of OAOs in our sample, these results provide a cleaner test of the relationship between underwriting fees and OAOs than is possible using U.S. data where OAOs are almost universal.

A further examination of table 5 suggests that lnoffer and oaoprcnt are always significant whether or not interaction terms are included. The reputation variable rank and the retstdev variable are significant in the absence of the rank $\times$ std interaction term. The positive coefficient on the interaction term rank $\times$ std suggests that a higher rank or lower underwriter reputation (i.e., one type of issue risk) together with a higher standard deviation of returns (i.e., a second type of issue risk) are jointly associated with higher underwriter fees.

In terms of explaining the variation in underwriter fees, regression 2 performs best and also represents a parsimonious relationship between fees and its determinants. It is given by

$$
\begin{aligned}
& \text { Underwriter Fee }=14.938-0.542 \text { lnoffer } \\
& \quad+0.032 \text { oaoprcnt }+0.009 \text { rank } \times \text { std }
\end{aligned}
$$

\section{Evidence of Price Stabilization and the Role of the Overallotment Option}

This section begins with a test to determine if market price stabilization is detectable in the short-run aftermarket for Canadian IPOs. This is done by first examining the intertemporal behavior in the short-run aftermarket of various indicators of market stabilization for the sample of IPOs; namely, the cross-sectional distributions of returns, the adjusted Tobit mean returns, and the bid-ask spreads. Given evidence of detectable market price stabilization, the extent to which the inclusion of an OAO is a determinant of the average level of detectable market price stabilization is then examined. 


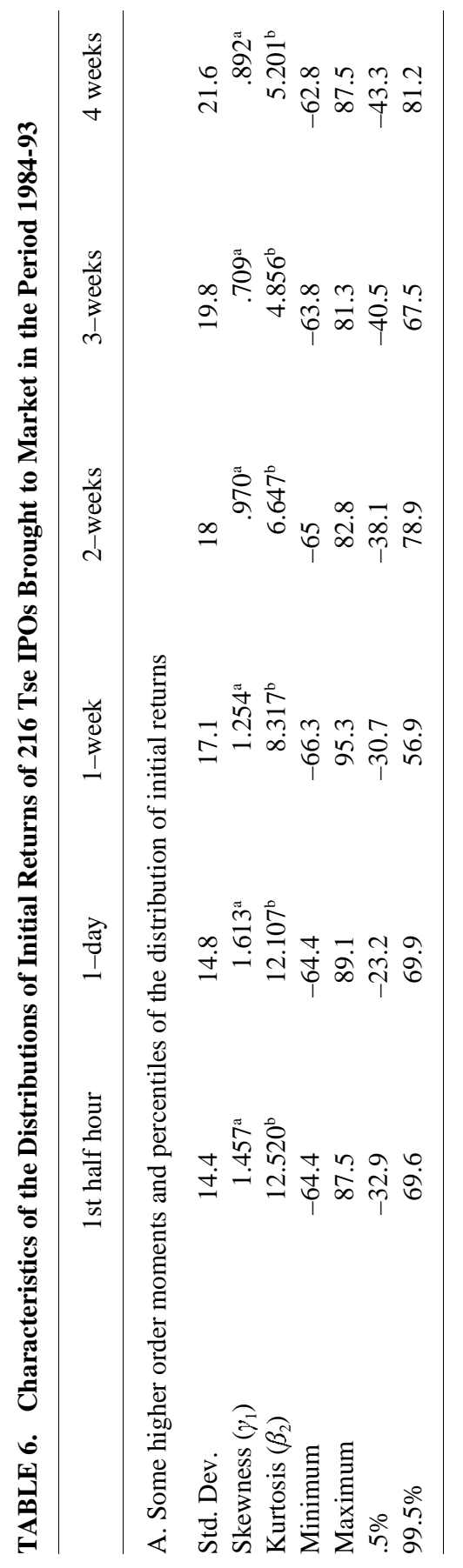




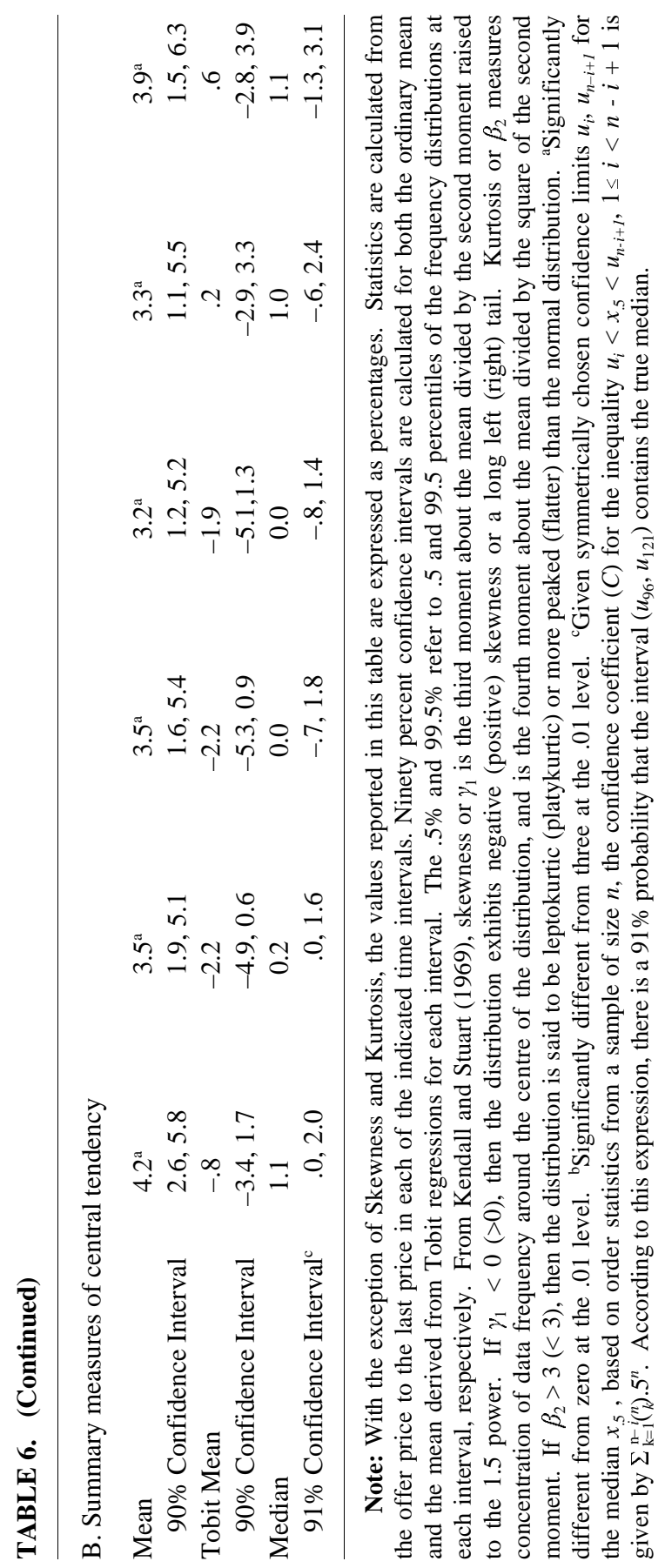



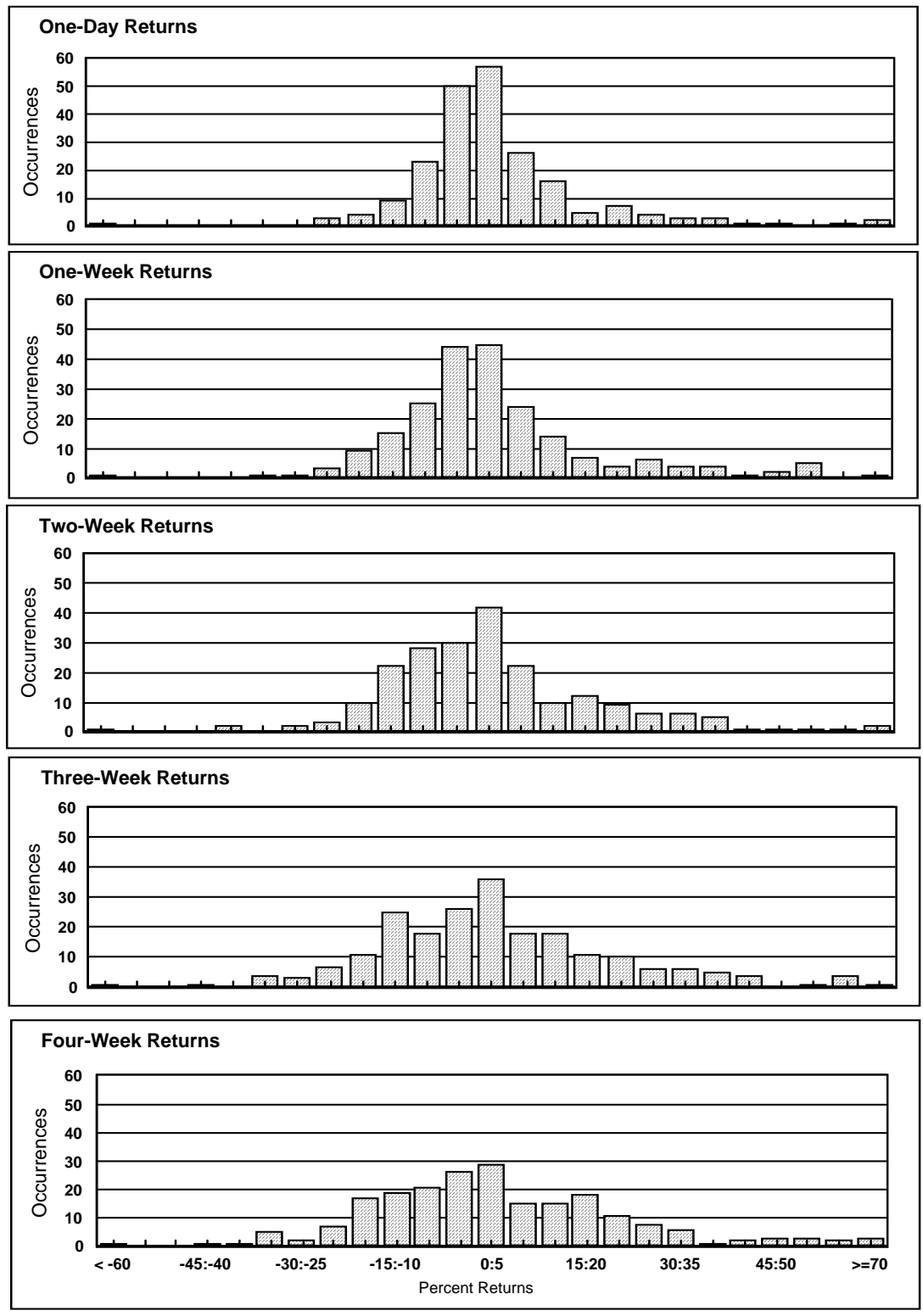

FIGURE 1.- Initial Return Histograms of 216 TSE IPOs, 1984-93. Each range starts at the first indicated value and continues to, but does not include, the second. For example, the range 0:5 includes returns between 0 and $4.999 \%$. 


\section{A. The Distribution of Short-Term IPO Returns}

If the price of an IPO is being supported, the distribution of returns should be positively skewed (since the negative tail of the distribution is being suppressed). The severity of this skewness should decrease over time as the effects of stabilization diminish. In addition, there should be excess peaking of the distribution around zero as otherwise negative returns are pushed up and become positive. The degree of leptokurtosis of the distribution also should decay over time.

Based on the summary measures that characterize the return distribution that are reported in panel A of table 6 , skewness $\left(\gamma_{1}\right)$ is positive and consistently different from zero at each point in time, and reaches a peak sometime during the first day of secondary market trading and tends to decrease steadily thereafter. The measure of kurtosis $\left(\beta_{2}\right)$ indicates that the distribution is considerably more peaked than the normal distribution at each point in time and also tends to decrease over time.

A visual testimony to the presence of positive skewness and excess kurtosis is given in figure 1 . There is clear evidence of distribution asymmetry and extreme peakedness at day one along with the tendency for these measures to decrease with time. In particular, the ratio of the frequency of returns in the $0-5 \%$ range at week four compared to that of day one is exactly one-half ( 29 occurrences at the end of week four compared to 58 occurrences at the end of day one).

Another interesting feature of the time series of return distributions is the migration of the minimum return. ${ }^{10}$ The .5 percentile of the distribution declines from a maximum of -.232 at the end of the first day, to -.433 at the end of week four. On the other hand, the 99.5 percentile of the distribution cycles up and down over the same period of time. These data suggest that the minimum return is free to drop when stabilization is removed while the lack of price intervention on the upside allows the maximum return to bounce around in a random fashion.

10. We compute .5 and 99.5 percentiles of the return distributions as alternatives to the minimum and maximum values in an attempt to mitigate the possible influence of outliers. Since the sample contains 216 observations at each point in time, only the smallest and largest values are effectively omitted. 


\section{B. Test for Market Price Stabilization Based on the Adjusted Tobit Mean Returns}

Ruud (1993) tests the underwriter price support hypothesis and concludes that a partially unobserved negative tail drives underpricing. Since stabilization effectively left censors the distribution of returns (prices) at zero (the offer price), a Tobit regression should yield an estimate of the true mean return (adjusted for stabilization). ${ }^{11}$ The specification of the model to be estimated is:

$$
r_{t}^{*}=\mu+\varepsilon_{t}
$$

where $r_{t}^{*}$ is the true return vector at time $t ; \mu$ is the true mean return; $\varepsilon_{t} \sim N\left(0, \sigma^{2}\right)$; and $r_{t}$ is the vector of observed returns at time $t$, or:

$$
r_{t}\left\{\begin{array}{l}
r_{t}^{*} \text { if } r_{t}^{*}>0 \\
0 \text { if } r_{t}^{*} \leq 0
\end{array}\right.
$$

The true mean return $\mu$ at each point in time is estimated using maximum likelihood estimation procedures, and a likelihood ratio test is employed for the purposes of hypothesis testing.

Based on the results reported in panel B of table 6 , the sample mean return for TSE IPOs is significantly different from zero at the $1 \%$ level at each point in time. However, the estimate of the true mean return determined by the Tobit regressions varies from a low of $-2.2 \%$ at the end of day one and week one to a high of .6\% at the end of week four. In each case, the Tobit mean is not significantly different from zero at the $1 \%$ level. The sample median displays qualitatively similar behavior. In order to compare the ordinary mean and the Tobit mean, $90 \%$ confidence intervals around the two means are computed at each point

11. There is a subtle difference between censoring and truncation. When a distribution is truncated from the left (right), sample points below (above) some threshold are ignored. On the other hand, when a distribution is censored from the left (right), sample points below (above) some threshold are assumed to occur at the threshold. In this sample, returns that might otherwise be negative, are assumed to be zero (i.e. left censored at zero). 
in time. The confidence intervals do not overlap until week 2. This suggests that the two means are initially different from each other. ${ }^{12}$ Moreover, the Tobit mean and the median tend to approach each other over time. This is another indication that the distribution of returns is becoming symmetrical as stabilization forces are withdrawn. As further evidence, a 90\% confidence interval for the Tobit mean overlaps a 91\% confidence interval for the median at each point in time. Thus, the hypothesis that the Tobit mean and the median are equal is not rejected by the data. This indicates that the distribution of returns would be symmetrical (since the mean and median are likely to coincide) if stabilization was absent.

\section{Test for Market Price Stabilization Based on the Bid-Ask Spreads}

Hanley, Kumar and Seguin (1993) suggest that market makers react to stabilization by adjusting their bid-ask spreads. If underwriters (the price stabilizers) stand ready to support the price by buying shares at the IPO offer price, the maximum loss that a market maker incurs on his inventory of shares held should decline. ${ }^{13}$ Although the market maker does not participate in the stabilization process, the market maker nevertheless can afford to narrow the spread as the price declines since the cost of supplying immediacy is reduced. Consequently, the ratio of the bid price to the stabilization price can be taken as a proxy for IPO.

12. $95 \%$ confidence intervals for the two means also do not overlap until week 2 post-

13. On the Toronto Stock Exchange the market maker is called the registered trader (RT). One RT is assigned to each stock upon the initial listing of the stock. The assignment is based on three weighted criteria including past performance $(50 \%)$, service levels $(25 \%)$ and other considerations (25\%). An average RT is responsible for approximately eleven securities. The role of the RT is small compared to the NYSE specialist or NASDAQ market maker due mainly to the transparency of the market. The RT does not have any proprietary pre-trade information and does not have access to any information regarding orders entered by others. The RT acts primarily as a supplier of liquidity, and is generally not associated with the underwriting syndicate. Interviews with industry personnel suggest that distribution complications can arise when the RT is associated with one of the members of the underwriting syndicate. For example, investment dealers being advised that they should advise their clients to buy the issue may be troubled when they see that the investment dealer whose dealer number is used to clear the RT's trade is trading on both sides of the market. 
stabilization. By including other factors that are known to affect the size of the spread (such as share volume, price and volatility), a regression of the relative spread on these factors and the stabilization proxy should yield a significant and positive coefficient for the proxy if market makers are indeed adjusting their quoted spreads to account for stabilization.

Alternatively, stabilization can be compared to a protective put option with exercise price equal to the floor value (stabilization price) of the stock. ${ }^{14}$ In this case, the Black-Scholes value of a European put option can be written as:

$$
\begin{gathered}
p=(\text { Offer Price }) \times e^{-r_{f}(T-t)} \times N\left(-d_{2}\right) \\
-(\text { Closing Bid Price }) \times N\left(-d_{1}\right),
\end{gathered}
$$

where,

$$
d_{1}=\frac{\ln (\text { Bid / Offer })+\left(r_{f}+\frac{1}{2} \sigma^{2}\right)(T-t)}{\sigma \sqrt{T-t}}
$$

and

$$
d_{2}=d_{1}-\sigma \sqrt{T-t} \text {. }
$$

Following Hanley et al, $r_{f}=0$ and $T$ - $t$ (the time to maturity) $=1$. In an effort to minimize the impact of heteroskedasticity, volatility is calculated in the following way:

$$
\text { Volatility }_{j, t}=\left\{\begin{array}{cc}
\sigma_{1: 11} & \text { if } t \leq 6 \\
\sigma_{t-5: t+5} & \text { if } t>6
\end{array}\right. \text {. }
$$

In other words, the volatility for security $j$ on day $t$ is constant for the first six days and is just the standard deviation of returns over the first

14. As is customary in this literature, we assume that the exercise price is the offer price. Regulation stipulates that stabilization cannot occur at a price above the offer price but is silent about whether it can occur at prices below the offer price. Interviews with industry personnel indicate that occasionally the underwriter may chose to stabilize the price below the offer price while simultaneously attempting to place the unsold portion of the initial share offering with public investors. 
TABLE 7. Summary Statistics For The Two Stabilization Proxies Aggregated Over a Forty Day Period Post-IPO

\begin{tabular}{lcc}
\hline & Bid/Offer Proxy & Put Option Proxy \\
\hline Mean & 1.036 & .789 \\
Median & 1 & .005 \\
Standard Deviation & .216 & 1.321 \\
Minimum & .338 & 0 \\
25th Percentile & .911 & 0 \\
75th Percentile & 1.134 & 1.125 \\
Maximum & 2.4 & 14 \\
Skewness & 1.027 & 2.411 \\
Kurtosis & 6.359 & 11.284 \\
\hline
\end{tabular}

eleven days of secondary market trading. Thereafter, volatility is calculated on a rolling basis. For example, the volatility for day seven is the standard deviation of returns calculated over days two to twelve inclusive.

As the price of the stock declines, the value of the put option increases. ${ }^{15}$ Therefore a regression of the relative spread on the factors that affect the spread and the put option proxy should produce a significant and negative coefficient for this proxy if market makers systematically adjust their spreads.

Table 7 reports summary statistics for the two proxies aggregated across all stocks over the forty-day period. The average value of the Bid/Offer proxy is 1.036, which reflects the positive mean return that is earned initially. The typical value of this proxy is 1.000 , which reflects the high frequency with which the bid price is equal to the IPO offer price. The put option proxy is quite volatile, exhibits considerable skewness and kurtosis, and is typically close to zero in value. It is clear that the two stabilization proxies are not independent. In fact, the Bid/Offer proxy is contained in the values $d_{1}$ and $d_{2}$ that are used to compute the value of the put option proxy. A simple linear regression of the Bid/Offer proxy on the put option proxy produces an adjusted $R^{2}$ of .70. 
Two series of daily cross-sectional regressions of the natural logarithm of the relative spread on the three spread factors and the two stabilization proxies are run from day one through day forty post-IPO. Tables 8 and 9 report summaries of the output when the bid to offer proxy and the put option proxy, respectively, are used. ${ }^{16}$ The model employed here differs somewhat from that of Hanley, Kumar and Seguin (1993) in that their sample considered NASDAQ stocks with multiple dealers and therefore included a regressor for the number of dealers. Since TSE stocks have only one market maker, it is not necessary to control for this variable. In addition, the series of regressions that include the put option proxy is modified to be: $(1+$ put option) value. ${ }^{17}$ This step is necessary since approximately $44 \%$ of the put option values are zero and this would produce an undefined logarithm. ${ }^{18}$

Both sets of regressions explain the relative spread very well (adjusted $R^{2}$ as high as .519 for regression set one and .530 for regression set two). However, while the coefficients for volume, price and volatility are significant at conventional levels on nearly every day,

16. The same model with the two alternative proxies also is run over the first twenty days of trading against other measures of trading costs. In turn, this involves the following independent variables: the relative liquidity premium $(R L P)$ defined as, $R L P=[\mid$ Transaction Price $-1 / 2(B i d+A s k) \mid] /[1 / 2(B i d+A s k)]$; the $\ln (1+R L P)$; the depth weighted spread $(D W S)$ defined as, DWS $=[($ Ask $\times$ Ask Depth $)-($ Bid $\times$ Bid Depth $)] /[($ Ask $\times$ Ask Depth $)+($ Bid $\times$ Bid Depth)]; and $\ln (1+D W S)$. For the $R L P$ and $\ln (1+R L P)$, either of the two stabilization proxies are significant at $p<0.10$ on as many as five days but there is no apparent pattern to the days on which they are significant (days 2, 7, 8, 13 and 15). Moreover, the model typically explains only about 3 to $5 \%$ of the variation in the associated dependent variable. Regressions employing the depth weighted spread and $\ln (1+D W S)$ display poorer explanatory performance. The two stabilization proxies are never significant at $p<0.05$, and the adjusted $\mathrm{R}^{2}$ is often close to zero and is occasionally negative.

17. Discussions with a TSE official suggest that the exercise price of the put option need not be the offer price. Underwriters are permitted to stabilize prices at or below (but not above) the offer price. In the latter case, this would likely occur if the underwriter had excess inventory that they are having difficulty selling. Results using the put option proxy should therefore be biased in favor of finding significant coefficients, since choosing the exercise price to be the offer price will effectively increase the value of the put option at least part of the time.

18. See the appendix for a theoretical explanation of the relatively high incidence of zero put option values. 
TABLE 8. Daily Cross-sectional Regressions of the Relative Spread on Factors Known to Affect the Spread and the Bid/Offer Stabilization Proxy

\begin{tabular}{|c|c|c|c|c|c|c|c|}
\hline Day & Intercept & $\ln$ (Volume) & $\begin{array}{c}\ln \\
\text { (idspread) }\end{array}$ & $\begin{array}{c}\ln \\
\text { (Volatility) }\end{array}$ & $\begin{array}{l}\ln (\text { Bid price/ } \\
\text { Offer price })\end{array}$ & $N$ & Adj. $R^{2}$ \\
\hline 1 & $\begin{array}{l}-1.654 \\
(-8.29)\end{array}$ & $\begin{array}{c}-.071 \\
(-4.63)\end{array}$ & $\begin{array}{r}-.624 \\
(-10.71)\end{array}$ & $\begin{array}{l}.108 \\
(3.42)\end{array}$ & $\begin{array}{l}-.007 \\
(-.04)\end{array}$ & 216 & .519 \\
\hline 2 & $\begin{array}{r}-2.301 \\
(-10.78)\end{array}$ & $\begin{array}{r}-.021 \\
(-1.21)\end{array}$ & $\begin{array}{r}-.637 \\
(-10.59)\end{array}$ & $\begin{array}{r}.083 \\
(2.49)\end{array}$ & $\begin{array}{l}-.024 \\
(-.13)\end{array}$ & 212 & .456 \\
\hline 3 & $\begin{array}{l}-1.894 \\
(-7.21)\end{array}$ & $\begin{array}{r}-.072 \\
(-3.49)\end{array}$ & $\begin{array}{r}-.502 \\
(-7.19)\end{array}$ & $\begin{array}{r}.124 \\
(3.14)\end{array}$ & $\begin{array}{l}.167 \\
(.79)\end{array}$ & 211 & .340 \\
\hline 4 & $\begin{array}{l}-1.646 \\
(-7.25)\end{array}$ & $\begin{array}{r}-.085 \\
(-4.58)\end{array}$ & $\begin{array}{c}-.533 \\
(-7.65)\end{array}$ & $\begin{array}{r}.134 \\
(3.56)\end{array}$ & $\begin{array}{l}.135 \\
(.69)\end{array}$ & 214 & .415 \\
\hline 5 & $\begin{array}{l}-1.864 \\
(-9.74)\end{array}$ & $\begin{array}{r}-.065 \\
(-4.09)\end{array}$ & $\begin{array}{c}-.554 \\
(-9.04)\end{array}$ & $\begin{array}{r}.122 \\
(3.78)\end{array}$ & $\begin{array}{l}.052 \\
(.32)\end{array}$ & 210 & .477 \\
\hline 6 & $\begin{array}{l}-1.818 \\
(-7.84)\end{array}$ & $\begin{array}{c}-.093 \\
(-4.60)\end{array}$ & $\begin{array}{c}-.533 \\
(-7.65)\end{array}$ & $\begin{array}{r}.078 \\
(2.08)\end{array}$ & $\begin{array}{r}.546 \\
(2.89)\end{array}$ & 207 & .386 \\
\hline 7 & $\begin{array}{l}-2.060 \\
(-9.99)\end{array}$ & $\begin{array}{c}-.049 \\
(-2.55)\end{array}$ & $\begin{array}{c}-.616 \\
(-9.51)\end{array}$ & $\begin{array}{r}.065 \\
(2.65)\end{array}$ & $\begin{array}{r}.207 \\
(1.25)\end{array}$ & 206 & .426 \\
\hline 8 & $\begin{array}{l}-2.034 \\
(-8.68)\end{array}$ & $\begin{array}{c}-.070 \\
(-3.14)\end{array}$ & $\begin{array}{r}-.567 \\
(-8.46)\end{array}$ & $\begin{array}{r}.052 \\
(2.03)\end{array}$ & $\begin{array}{r}.257 \\
(1.42)\end{array}$ & 203 & .376 \\
\hline 9 & $\begin{array}{l}-2.026 \\
(-9.02)\end{array}$ & $\begin{array}{r}-.041 \\
(-2.21)\end{array}$ & $\begin{array}{c}-.609 \\
(-9.26)\end{array}$ & $\begin{array}{r}.090 \\
(2.91)\end{array}$ & $\begin{array}{l}-.079 \\
(-.47)\end{array}$ & 206 & .417 \\
\hline 10 & $\begin{array}{l}-1.888 \\
(-8.44)\end{array}$ & $\begin{array}{r}-.059 \\
(-3.20)\end{array}$ & $\begin{array}{c}-.626 \\
(-9.25)\end{array}$ & $\begin{array}{r}.075 \\
(2.37)\end{array}$ & $\begin{array}{l}.044 \\
(.25)\end{array}$ & 207 & .415 \\
\hline 15 & $\begin{array}{l}-1.272 \\
(-4.97)\end{array}$ & $\begin{array}{c}-.100 \\
(-5.32)\end{array}$ & $\begin{array}{r}-.480 \\
(-6.73)\end{array}$ & $\begin{array}{r}.203 \\
(4.24)\end{array}$ & $\begin{array}{c}-.266 \\
(-1.64)\end{array}$ & 206 & .445 \\
\hline 20 & $\begin{array}{l}-1.652 \\
(-5.82)\end{array}$ & $\begin{array}{r}-.035 \\
(-1.66)\end{array}$ & $\begin{array}{r}-.619 \\
(-8.08)\end{array}$ & $\begin{array}{r}.174 \\
(3.30)\end{array}$ & $\begin{array}{l}-.082 \\
(-.49)\end{array}$ & 200 & .416 \\
\hline 25 & $\begin{array}{l}-1.459 \\
(-5.83)\end{array}$ & $\begin{array}{r}-.074 \\
(-3.83)\end{array}$ & $\begin{array}{r}-.639 \\
(-9.04)\end{array}$ & $\begin{array}{r}.129 \\
(2.69)\end{array}$ & $\begin{array}{r}.185 \\
(1.27)\end{array}$ & 201 & .468 \\
\hline 30 & $\begin{array}{l}-1.660 \\
(-5.64)\end{array}$ & $\begin{array}{r}-.070 \\
(-3.52)\end{array}$ & $\begin{array}{r}-.544 \\
(-6.98)\end{array}$ & $\begin{array}{r}.130 \\
(2.39)\end{array}$ & $\begin{array}{l}-.116 \\
(-.73)\end{array}$ & 202 & .356 \\
\hline Total 1\% & 40 & 33 & 40 & 28 & 1 & & \\
\hline Total 5\% & 40 & 36 & 40 & 38 & 2 & & \\
\hline Total $10 \%$ & 40 & 39 & 40 & 40 & 2 & & \\
\hline
\end{tabular}

Note: The logarithm of the daily closing relative spread is regressed cross-sectionally on the respective logarithms of daily share volume, closing midspread, calculated as (closing bid + closing ask)/2, volatility, calculated on a rolling basis similar to Hanley, Kumar and Seguin (1993), and the ratio of closing bid/offer price for each issue. Coefficients are estimated for each of the days 1 through 40 from regressions of the form:

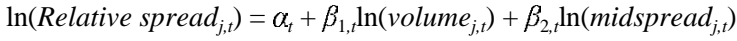

$$
\begin{aligned}
& +\beta_{3, t} \ln \left(\text { volatility }_{j, t}\right)+\beta_{4, t} \ln \left(\text { bid/offer }_{j, t}\right)
\end{aligned}
$$

$t$-statistics for the coefficient estimates appear in the parentheses. The last three lines of the table give a summary of the number of times each coefficient is significantly different from zero at the $1 \%, 5 \%$ and $10 \%$ levels over the forty day period. 
TABLE 9. Daily Cross-sectional Regressions of the Relative Spread on Factors Known to Affect the Spread and the Put Option Stabilization Proxy

\begin{tabular}{|c|c|c|c|c|c|c|c|}
\hline Day & Intercept & $\ln ($ Volume $)$ & $\begin{array}{c}\ln \\
\text { (Midspread) }\end{array}$ & $\begin{array}{c}\ln \\
\text { (Volatility) }\end{array}$ & $\begin{array}{l}\ln (\text { Bid price/ } \\
\text { Offer Price) }\end{array}$ & $N$ & Adj. $R^{2}$ \\
\hline 1 & $\begin{array}{l}-1.559 \\
(-7.73)\end{array}$ & $\begin{array}{c}-.066 \\
(-4.37)\end{array}$ & $\begin{array}{c}-.558 \\
(-8.78)\end{array}$ & $\begin{array}{r}.173 \\
(4.17)\end{array}$ & $\begin{array}{c}-.192 \\
(-2.24)\end{array}$ & 216 & .530 \\
\hline 2 & $\begin{array}{c}-2.230 \\
(-10.47)\end{array}$ & $\begin{array}{r}-.014 \\
(-0.76)\end{array}$ & $\begin{array}{r}-.569 \\
(-8.81)\end{array}$ & $\begin{array}{r}.149 \\
(3.57)\end{array}$ & $\begin{array}{r}-.197 \\
(-2.38)\end{array}$ & 212 & .471 \\
\hline 3 & $\begin{array}{l}-1.847 \\
(-7.01)\end{array}$ & $\begin{array}{r}-.065 \\
(-3.12)\end{array}$ & $\begin{array}{r}-.428 \\
(-5.61)\end{array}$ & $\begin{array}{r}.187 \\
(3.78)\end{array}$ & $\begin{array}{r}-.157 \\
(-1.63)\end{array}$ & 211 & .346 \\
\hline 4 & $\begin{array}{l}-1.652 \\
(-7.19)\end{array}$ & $\begin{array}{c}-.086 \\
(-4.55)\end{array}$ & $\begin{array}{r}-.528 \\
(-7.00)\end{array}$ & $\begin{array}{r}.135 \\
(2.84)\end{array}$ & $\begin{array}{c}.024 \\
(.27)\end{array}$ & 214 & .414 \\
\hline 5 & $\begin{array}{l}-1.855 \\
(-9.63)\end{array}$ & $\begin{array}{c}-.063 \\
(-3.92)\end{array}$ & $\begin{array}{c}-.533 \\
(-8.02)\end{array}$ & $\begin{array}{r}.139 \\
(3.39)\end{array}$ & $\begin{array}{l}-.038 \\
(-.48)\end{array}$ & 210 & .477 \\
\hline 6 & $\begin{array}{l}-1.856 \\
(-7.78)\end{array}$ & $\begin{array}{c}-.090 \\
(-4.29)\end{array}$ & $\begin{array}{r}-.481 \\
(-6.26)\end{array}$ & $\begin{array}{r}.107 \\
(2.20)\end{array}$ & $\begin{array}{l}.028 \\
(.30)\end{array}$ & 207 & .361 \\
\hline 7 & $\begin{array}{c}-2.088 \\
(-10.14)\end{array}$ & $\begin{array}{r}-.048 \\
(-2.48)\end{array}$ & $\begin{array}{c}-.603 \\
(-9.11)\end{array}$ & $\begin{array}{r}.067 \\
(2.66)\end{array}$ & $\begin{array}{l}.018 \\
(.28)\end{array}$ & 206 & .422 \\
\hline 8 & $\begin{array}{l}-2.073 \\
(-8.90)\end{array}$ & $\begin{array}{r}-.069 \\
(-3.03)\end{array}$ & $\begin{array}{r}-.561 \\
(-8.22)\end{array}$ & $\begin{array}{r}.052 \\
(1.96)\end{array}$ & $\begin{array}{l}.061 \\
(.87)\end{array}$ & 203 & .372 \\
\hline 9 & $\begin{array}{l}-2.010 \\
(-9.00)\end{array}$ & $\begin{array}{r}-.042 \\
(-2.23)\end{array}$ & $\begin{array}{r}-.621 \\
(-9.38)\end{array}$ & $\begin{array}{r}.086 \\
(2.71)\end{array}$ & $\begin{array}{l}.009 \\
(.14)\end{array}$ & 206 & .416 \\
\hline 10 & $\begin{array}{l}-1.873 \\
(-8.41)\end{array}$ & $\begin{array}{c}-.062 \\
(-3.26)\end{array}$ & $\begin{array}{r}-.635 \\
(-9.40)\end{array}$ & $\begin{array}{r}.071 \\
(2.20)\end{array}$ & $\begin{array}{l}.049 \\
(.71)\end{array}$ & 207 & .416 \\
\hline 15 & $\begin{array}{l}-1.184 \\
(-4.77)\end{array}$ & $\begin{array}{c}-.093 \\
(-5.08)\end{array}$ & $\begin{array}{r}-.405 \\
(-5.53)\end{array}$ & $\begin{array}{r}.259 \\
(5.18)\end{array}$ & $\begin{array}{r}-.232 \\
(-3.55)\end{array}$ & 206 & .471 \\
\hline 20 & $\begin{array}{l}-1.651 \\
(-6.00)\end{array}$ & $\begin{array}{r}-.029 \\
(-1.35)\end{array}$ & $\begin{array}{r}-.549 \\
(-6.86)\end{array}$ & $\begin{array}{r}.211 \\
(3.86)\end{array}$ & $\begin{array}{l}-.153 \\
(-2.22)\end{array}$ & 200 & .430 \\
\hline 25 & $\begin{array}{l}-1.543 \\
(-6.32)\end{array}$ & $\begin{array}{r}-.070 \\
(-3.55)\end{array}$ & $\begin{array}{c}-.594 \\
(-8.08)\end{array}$ & $\begin{array}{r}.140 \\
(2.76)\end{array}$ & $\begin{array}{l}-.019 \\
(-.31)\end{array}$ & 201 & .463 \\
\hline 30 & $\begin{array}{l}-1.630 \\
(-5.64)\end{array}$ & $\begin{array}{r}-.070 \\
(-3.45)\end{array}$ & $\begin{array}{c}-.541 \\
(-6.61)\end{array}$ & $\begin{array}{r}.137 \\
(2.43)\end{array}$ & $\begin{array}{l}-.043 \\
(-.66)\end{array}$ & 202 & .355 \\
\hline Total $1 \%$ & 40 & 33 & 40 & 30 & 1 & & \\
\hline Total 5\% & 40 & 36 & 40 & 37 & 4 & & \\
\hline Total $10 \%$ & 40 & 38 & 40 & 39 & 4 & & \\
\hline
\end{tabular}

Note: The logarithm of the daily closing relative spread is regressed cross-sectionally on the respective logarithms of daily share volume, closing midspread, calculated as (closing bid + closing ask $) / 2$, volatility, calculated on a rolling basis similar to Hanley, Kumar and Seguin (1993), and the ratio of closing bid/offer price for each issue. Coefficients are estimated for each of the days 1 through 40 from regressions of the form:

$$
\begin{gathered}
\ln \left(\text { Relative }_{\text {spread }}^{j, t}\right)=\alpha_{t}+\beta_{1, t} \ln \left(\text { volume }_{j, t}\right)+\beta_{2, t} \ln \left(\text { midspread }_{j, t}\right) \\
+\beta_{3, t} \ln \left(\text { volatility }_{j, t}\right)+\beta_{4, t} \ln \left(1+\text { put option }_{j, t}\right)
\end{gathered}
$$

$t$-statistics for the coefficient estimates appear in the parentheses. The last three lines of the table give a summary of the number of times each coefficient is significantly different from zero at the $1 \%, 5 \%$ and $10 \%$ levels over the forty day period. 
the coefficients for the two stabilization proxies are rarely significant. The coefficient for the Bid/Offer proxy is not significant until day six and is only significant on two of the forty days. The coefficient of the put option proxy is significant on the first two days, but is only significant on four of the forty days. ${ }^{19}$ Thus, it appears that in contrast to the findings of Hanley, Kumar and Seguin (1993), market makers on the TSE are less active in adjusting the size of the spread to reflect stabilizing trades by underwriters for Canadian IPOs.

\section{Test for the Role of the OAO in Market Price Stabilization Based on the Adjusted Tobit Mean Returns}

If an OAO is indeed a mechanism used by underwriters to stabilize prices, one would expect that the difference between ordinary and adjusted (Tobit) mean returns should be larger for the OAO sample than for the sample that does not contain an OAO during the period when the $\mathrm{OAO}$ is alive. Table 10 reports ordinary and adjusted mean returns at different points in time for the OAO and No-OAO sample. For both samples, the ordinary mean returns are generally significantly different from zero at each point in time while the adjusted mean returns are never significantly different from zero. Although the difference between the ordinary and adjusted means is larger for the OAO sample at days five, ten, fifteen and twenty, the difference in the differences is not significant at any point in time. Thus, it does not seem that the presence of the OAO has any measurable impact on correctly measured mean returns over the life of the option.

19. This test of stabilization activity may not be powerful enough to detect stabilization if it is present. Hence two additional sets of paired regressions were run as a robustness check. In the first case, only non-underpriced issues are included. In the second case, since stabilization is a capital-intensive exercise, it may be possible that smaller underwriters do not have the financial resources to support the price. Therefore, only nonunderpriced issues whose lead or co-lead underwriter is one of the four largest underwriters in Canada over the sample period are considered. In both cases the number of significant coefficients is virtually identical to those reported for the full sample. Tables with this additional evidence were suppressed to save valuable journal space. 
TABLE 10.Ordinary and Adjusted Mean Returns With/Without an Overallotment Option

\begin{tabular}{|c|c|c|c|c|c|c|}
\hline & \multicolumn{3}{|c|}{ OAO Returns: 56} & \multicolumn{3}{|c|}{ No- OAO Returns: 124} \\
\hline & $\begin{array}{l}\text { Ordinary } \\
\text { mean }\end{array}$ & $\begin{array}{l}\text { Tobit } \\
\text { mean }\end{array}$ & $\begin{array}{l}\text { Difference } \\
\text { in means }\end{array}$ & $\begin{array}{l}\text { Ordinary } \\
\text { mean }\end{array}$ & $\begin{array}{l}\text { Tobit } \\
\text { mean }\end{array}$ & $\begin{array}{l}\text { Difference } \\
\text { in means }\end{array}$ \\
\hline 1 Day & $\begin{array}{l}3.933 \\
(3.09)\end{array}$ & $\begin{array}{c}-2.003 \\
(-.73)\end{array}$ & 5.936 & $\begin{array}{l}3.860 \\
(2.45)\end{array}$ & $\begin{array}{l}-2.257 \\
(-.89)\end{array}$ & 6.117 \\
\hline 5 Day & $\begin{array}{l}4.997 \\
(2.48)\end{array}$ & $\begin{array}{c}-1.429 \\
(-.40)\end{array}$ & 6.426 & $\begin{array}{c}3.474 \\
(2.10)\end{array}$ & $\begin{array}{c}-2.585 \\
(-.96)\end{array}$ & 6.059 \\
\hline 10 Day & $\begin{array}{l}4.601 \\
(2.05)\end{array}$ & $\begin{array}{c}-1.433 \\
(-.37)\end{array}$ & 6.034 & $\begin{array}{c}3.386 \\
(1.95)\end{array}$ & $\begin{array}{c}-1.614 \\
(-.60)\end{array}$ & 5.000 \\
\hline 15 Day & $\begin{array}{c}4.916 \\
(1.77)\end{array}$ & $\begin{array}{c}.979 \\
(.245)\end{array}$ & 3.937 & $\begin{array}{c}3.439 \\
(1.92)\end{array}$ & $\begin{array}{l}-.289 \\
(-.11)\end{array}$ & 3.728 \\
\hline 20 Day & $\begin{array}{l}7.123 \\
(2.41)\end{array}$ & $\begin{array}{l}2.701 \\
(.63)\end{array}$ & 4.422 & $\begin{array}{c}3.267 \\
(2.01)\end{array}$ & $\begin{array}{c}.611 \\
(.23)\end{array}$ & 2.656 \\
\hline 40 Day & $\begin{array}{c}11.176 \\
(2.97)\end{array}$ & $\begin{array}{c}6.449 \\
(1.25)\end{array}$ & 4.727 & $\begin{array}{c}5.290 \\
(2.46)\end{array}$ & $\begin{array}{c}-1.795 \\
(-.47)\end{array}$ & 7.085 \\
\hline 60 Day & $\begin{array}{c}11.580 \\
(2.52)\end{array}$ & $\begin{array}{c}7.611 \\
(1.28)\end{array}$ & 3.969 & $\begin{array}{c}7.820 \\
(2.92)\end{array}$ & $\begin{array}{c}-1.013 \\
(-.22)\end{array}$ & 8.833 \\
\hline
\end{tabular}

Note: Returns are calculated from the offer price to the price at the end of the day shown in the first column for each issue depending on whether there was an overallotment option granted or not. Mean returns are then computed cross-sectionally at each point in time and $t$-test values are included in the parentheses for the hypothesis that the respective mean is equal to zero. In addition, differences between ordinary and adjusted means for the OAO sample and the No-OAO sample are computed. Differences between the two sample differences are not significantly different from each other at both 5\% and $10 \%$ levels.

\section{Concluding Remarks}

Unlike the case for U.S. IPOs, we find evidence that the OAO has a positive impact on the fees charged by underwriters of Canadian IPOs when we control for factors such as issue size, underwriter reputation and issue risk. This is possibly one reason why Canadian firms are more reluctant to grant OAOs than American firms. Another possible (and completely untested) reason may lie in a recent working paper by Loughran and Ritter (2000) that suggests that American companies are, 
in general, not particularly upset about leaving money on the table (due to significant underpricing) in IPOs. In many instances, the value of these firms and the values of the holdings of large block shareholders and corporate management (including stock options) are often multiplied several times over in a matter of days. The attitude taken by many of these firms may be one of "let's give the underwriter all the ammunition it needs and then sit back and wait for our money to pour in." Thus, U.S. managers may be motivated by the prospect of significant wealth accumulation brought about by the IPO. The situation in Canada may be different. IPO underpricing in Canada is virtually the lowest of any industrialized country in the world, and IPO underwriting fees are lower and less concentrated in Canada compared to the U.S. ${ }^{20}$ Since the likelihood of significant wealth accumulation for principals of Canadian firms is substantially less than that for principals of U.S. firms, Canadian firms going public may be expected to agree less often to the inclusion of additional marketing incentives (such as OAOs) to underwriting arrangements. This also may be the reason why the granting of OAOs is positively (and not negatively) related to underwriting fees in Canada for IPOs. However, many other potential reasons for explaining the difference in OAO use in the U.S. and Canada for IPOs exist, and remain to be tested in future work.

This paper also finds that stabilizing activities by underwriters appear to affect the distribution of returns for TSE IPOs. Return distributions tend to be positively skewed and leptokurtic, and the degree of skewness and leptokurtosis tends to decrease over time as stabilizing forces diminish. Further, while ordinary mean returns are significantly different from zero out to week four post-IPO, Tobit means which account for the censoring of the distribution due to stabilization activities are not significantly different from zero. Moreover, $90 \%$ confidence intervals for the mean and the Tobit mean do not overlap until the end of the second week post-IPO, which indicates that the two means are indeed initially different from each other.

Consistent with the reduced effects of stabilization over time, the .5

20. For IPO underpricing, please see "Average First Day Returns for 37 Countries" under IPO DATA on Jay Ritter's website at ritter@dale.cba.ufl.edu. For IPO underwriting fees, please refer to Kryzanowski and Rakita (1999). 
percentiles of the return distributions decrease out to week four. On the other hand, stabilization does not appear to affect the behavior of the market maker as measured by the size of the bid-ask spread. Regressions using either of two stabilization proxies are rarely significant over the first forty days of secondary market trading.

While some evidence of stabilization in the market for new equity issues in Canada is uncovered, this does not mean that the overallotment option is the mechanism by which stabilization is effected. Schultz and Zaman (1994) suggest that underwriters typically oversell IPOs. This short position is then covered by exercising an overallotment (Green Shoe) option if the issue is hot, or by buying shares at lower prices in the secondary market if the issue is cold. Smith (1986) remarks that the $\mathrm{OAO}$ is only valuable to the underwriter if an IPO is underpriced since the underwriter earns incremental commissions if the option is exercised. ${ }^{21}$ While discussions with several Canadian underwriters point to the OAO as an important mechanism by which prices for IPOs are stabilized in Canada, no significant difference between the differences in ordinary and adjusted mean returns for the OAO sample compared to the No-OAO sample are found. Thus, OAOs are probably used more to aid distributional motivation than to aid price stabilization in Canadian markets.

\section{Appendix: Possible Explanation for the High Incidence of Zero Values for the Protective Put Option Proxy for Market Stabilization}

This appendix outlines a brief explanation for the high incidence (44\%) of zero put option values when the protective put option proxy for stabilization is used. Under the assumptions that $r_{f}=0$ and $T-t=1$, the value of a BlackScholes European put option can be written as:

$$
p=(\text { Offer Price }) \times e^{r_{f}(T-t)} \times N\left(-d_{2}\right)
$$

21. This argument again ignores the question of whether or not an issue is oversold and fails to consider the additional revenue that underwriters can earn as long as they can buy at a discount and sell the additional shares at some higher price (not necessarily in excess of the offer price). 
$-($ Closing Bid Price $) \times N\left(-d_{1}\right)$,

where:

$$
d_{1}=\frac{\ln (\text { Bid / Offer })+\left(r_{f}+\frac{1}{2} \sigma^{2}\right)(T-t)}{\sigma \sqrt{T-t}},
$$

and

$$
d_{2}=d_{1}-\sigma \sqrt{T-t}
$$

We can write

$$
d_{1}=\left(\frac{1}{\sigma}\right) \ln (\text { Bid / Offer })+\frac{\sigma}{2} .
$$

It is clear from table 6 (Panel B) that over the first few weeks of secondary market trading the mean return, measured from the offer price to the closing price on a particular day, lies in the range of about $3-4 \%$. This means that there are many cases where the closing bid is very close to or is equal to the offer price. (Indeed, from table 7, the median Bid/Offer $=1$ ). Clearly when

$$
\text { Bid }=\text { Offer, } d_{1}=\frac{\sigma}{2} \text {. }
$$

While many TSE IPOs experience considerable trading activity in the first few hours of their lives, there is far less activity thereafter. Consequently for many IPOs, the volatility of returns may approach zero. Therefore $d_{l}$ is small and $N\left(d_{l}\right) \approx .5$. Similarly, when $\sigma$ is small, $d_{2}=d_{1}-\sigma=\sigma / 2-\sigma \approx 0$ and $N\left(d_{l}\right) \approx .5$. As a result: $p \approx($ Offer Price/2) $-($ Closing Bid Price/2) $\approx 0$ when Offer Price $=$ Closing Bid Price.

\section{References}

Aggarwal, R. 2000. Stabilization activities by underwriters after initial public offerings. Journal of Finance 55 (June): 1075-1103.

Benveniste, L. M.; Busuba, W.Y.; Wilhelm, Jr., W.J. 1996. Price stabilization as a bonding mechanism in new equity issues. Journal of Financial Economics $42: 223-255$.

Baron, D. 1982. A model of the demand for investment banking advising and distribution services for new issues. Journal of Finance 37 (September): 955-976.

Barry, C. B., and Jennings, R. H. 1993. The opening price performance of initial 
public offerings of common stock. Financial Management 22 (1) (Spring): 54-63.

Beatty, R. P. and Ritter, J. R. 1986. Investment banking, reputation, and the underpricing of initial public offerings. Journal of Financial Economics 15: 213-232.

Black, F., and Scholes, M. 1973. The pricing of options and corporate liabilities. Journal of Political Economy 81 (May-June): 637-654.

Carter, R. B., and Dark, F. H. 1990. The Use of the overallotment option in initial public offerings of equity: Risks and underwriter prestige. Financial Management 19 ( 3) (Autumn): 55-64.

Carter, R.B., and Manaster, S. 1990. Initial public offerings and underwriter reputation. Journal of Finance 45 (4) (September): 1045-1067.

Cheung, C. S., and Krinsky, I. 1994. Information asymmetry and the underpricing of initial public offerings: Further empirical evidence. Journal of Business Finance \& Accounting 21 (5) (July): 739-747.

Chowdhry, B., and Nanda, V. 1996. Stabilization, syndication, and pricing of ipos. Journal of Financial and Quantitative Analysis 31 (1) (March): 25-42.

Ellis, K.; Michaely, R.; and O'Hara, M. 2000. When the underwriter is the market maker: an examination of trading in the ipo aftermarket. Journal of Finance 55 (June): 1039-1074.

Hansen, R. 1986. Evaluating the costs of a new equity issue. Midland Corporate Finance Journal 4 (1) (Spring): $42-55$.

Hansen, R.; Fuller, B. R.; and Janjigian, V. 1987. The overallotment option and equity financing flotation costs: An empirical investigation. Financial Management 16 (2) (Summer): 55-64.

Hanley, K. W.; Kumar, A. A.; and Seguin, P.J. 1993. Price stabilization in the market for new issues. Journal of Financial Economics 34 : 177-197.

Ibbotson, R. G. 1975. Price performance of common stock new issues. Journal of Financial Economics 2 : 235-272.

Ibbotson, R. G.; Sindelar, J. L.; and Ritter, J. R. 1988. Initial public offerings. Journal of Applied Corporate Finance (Summer): 37-45.

Jog, V. M.; and Riding, A. L. 1987. Underpricing in Canadian ipos. Financial Analysts Journal (November-December): 48-55.

Jog, V. M., and Srivastava, A. K. 1996. The Canadian environment for initial public offerings: Underpricing, long-term performance and the process of going public. Working Paper, School of Business, Carleton University, Ottawa, Canada.

Loughran, T., and Ritter, J. R. 2000. Why don't issuers get upset about leaving money on the table in ipos? Working Paper.

Kendall, M. G., and Stuart, A. 1969. The Advanced Theory of Statistics, 3rd ed. New York, NY, Hafner.

Kryzanowski, L., and Rakita, I. 1999. Is the U.S. 7\% solution equivalent to the Canadian 6\% solution? Canadian Investment Review 12 (3): 27-34. 
Kryzanowski, L.,and Rakita, I. 1996. The short-run intraday behaviour of Canadian ipos. Proceedings of the Administrative Sciences Association of Canada 17 (1): 41-50.

Megginson, W. L., and Weiss, K. A. 1991. Venture capitalist certification in initial public offerings. Journal of Finance 46 (3) (July): 879-903.

Merton, R. C. 1973. Theory of rational option pricing. Bell Journal of Economics and Management Science 4 (Spring): 141-183.

Miller, R. E., and Reilly, F.K. 1987. An examination of mispricing, returns and uncertainty for initial public offerings. Financial Management 16 (2): 3338.

Rock, K. 1986. Why new issues are underpriced. Journal of Financial Economics $15: 187-212$.

Ruud, J. S. 1993. Underwriter price support and the ipo underpricing puzzle. Journal of Financial Economics 34: 135-151.

Schultz, P. H., and Zaman, M. A. 1994. Aftermarket Support and Underpricing of Initial Public Offerings. Journal of Financial Economics 35: 199-219.

Smith, C. W. 1986. Raising capital: Theory and evidence. Midland Corporate Finance Journal 4 (1) (Spring): 6-22.

Tinic, S. M. 1988. Anatomy of initial public offerings of common stock. Journal of Finance 43 (September): 789-822.

Tobin, J. 1958. Estimation of relationships for limited dependent variables. Econometrica 26: 24-36.

Welch, I. 1989. Seasoned offerings, imitation costs, and the underpricing of initial public offerings. Journal of Finance 44 (June): 421-449.

Wolfe, G. A.; Cooperman, E. S.; and Ferris, S.P. 1994. An analysis of the underwriter selection process for initial public offerings. Journal of Financial Research 17 (1 ) (Spring): 77-90. 